\title{
Population's life quality assurance: food security
}

\author{
Gimadeev Aydar Damirovich \\ NChI Department of economic theory and economic policy \\ Kazan Federal University, \\ Kazan, Russia \\ fat.aydar.gimadeev@gmail.com
}

\author{
Makarov Anatolij Nikolaevich \\ NChI Department of economic theory and economic policy \\ Kazan Federal University, \\ Kazan, Russia \\ makarovfksu@yandex.ru
}

\begin{abstract}
This article is devoted to research of population's life quality assurance in interrelation with food security. Qualitative and quantitative methods of the analysis of data, methods of the comparative analysis and synthesis, methods of statistical data processing are applied. The result of the research is expressed in the recommendations of food security increase as one of the most important conditions of population's life quality assurance.
\end{abstract}

Keywords-Food security, quality of life, safety, population's satisfaction, indicators, level.

\section{INTRODUCTION}

Globalization of world economy raises questions of ensuring food security of national economies for the purpose of self-reliance strengthening, independence and sovereignty of the state. The benchmark of Russian Federation development is expressed in safety of the state, including food security increase for the purpose of life quality improvement and welfare of the population.

The purpose of the research is the analysis of a problem of population's life quality through ensuring food security.

A large number of works of the Russian scientists, such as Klimova N.W. [4], Samarukh V.I. [9], Sergeyeva I.A. [11], Sergeyev A.Y. [11], Khromova Y.S. [12], Chebotaryova M.S. [13] and others are devoted to questions of ensuring food security.

Such Russian scientists as Animitsa E.G. [1], BestuzhevaLada I. W. [2], Elokhova A. M [1], Mordovchenkova N.W. [6], Nikolaeva M.G. [6], Rimashevskaya N.M. [8], Sukhikh V.A. [1] and others did scientific research about analysis of indicators of life's quality.

Belekhov G. V. [14], Makarov A. N. [5], Sausheva O.S. [10], Shabunov A.A. [14] and others studied the influence of food security on population's life quality. Despite the knowledge, large volume of scientific works and publications, there are no works about influence of food security on population's life quality.

There are still insufficiently investigated key moments of interrelation of food security and population's life quality. The ways of improvement of population's life quality in connection with the priority directions of increase in food security of the country still are not defined.
Thus, carrying out systematic and comprehensive monitoring of assessment of population's life quality assumes identification of significant factors, definition of a technique of their assessment for adoption of the relevant effective decisions at the level of the state on improvement of ensuring food security of the country. In turn, the research of key problems of food security highlights the directions of increase in the level and quality of population's life.

\section{RESUlTS AND DiSCUSSION}

In recent years, problems of food security have been on the first place, because a considerable part of the Russian citizens has a poor food allowance. Norms of consumption of food per capita were significantly reduced that exerts negative impact on population's life quality. In turn, the worthy level and high population's life quality are the most important conditions of human development and factors of social and economic development of any state.

The modern social and economic situation in Russia, which has developed as a result of the decreasing living standards, high differentiation of the population's income, reductions of the production of the domestic food industry and consumption of potentially life-threatening and human health food, aggravates food security of the country [7]

For a more objective picture in the field of food security for the purpose of improvement of population's life quality, the authors have conducted a research (selection of 500 respondents in the temporary period of 2013-2017).

The respondents answered the following question: "Assess the level of the material prosperity" (table 1) [15].

TABLE I. ASSESSMENT OF MATERIAL WEALTH BY RESPONDENTS, IN PERCENT

\begin{tabular}{|l|l|l|l|l|l|}
\hline $\begin{array}{c}\text { Possible answers of } \\
\text { respondents }\end{array}$ & 2013 & 2014 & 2015 & 2016 & 2017 \\
\hline $\begin{array}{l}\text { Middle (food, clothes, } \\
\text { extremely necessary things, } \\
\text { payments, money is enough, } \\
\text { but to purchase expensive } \\
\text { things, it necessary to take } \\
\text { the credit or to save) }\end{array}$ & 61,6 & 61,1 & 59,4 & 56,2 & 54,8 \\
\hline $\begin{array}{l}\text { Poorly (for modest food, there } \\
\text { is enough money, but not for } \\
\text { acquisition of clothes and other } \\
\text { things and also payment of }\end{array}$ & 17,7 & 22,3 & 23,7 & 24,4 & 25,2 \\
\hline
\end{tabular}




\begin{tabular}{|l|l|l|l|l|l|}
\hline utilities) & & & & & \\
\hline $\begin{array}{l}\text { Prosperous (there is monetary } \\
\text { accumulation and an } \\
\text { opportunity to buy practically } \\
\text { all necessary for life) }\end{array}$ & 9,4 & 8,2 & 7,9 & 7,5 & 7,1 \\
\hline $\begin{array}{l}\text { Very poorly (there is almost no } \\
\text { money even for food and } \\
\text { payment) }\end{array}$ & 3,5 & 4,5 & 4,9 & 5,6 & 6,2 \\
\hline $\begin{array}{l}\text { Very well, wealthy (I don't } \\
\text { refuse anything, monetary } \\
\text { accumulation constantly } \\
\text { increases) }\end{array}$ & 1,4 & 1,0 & 1,0 & 1,0 & 0,9 \\
\hline Don't know / No answer & 6,4 & 2,9 & 3,1 & 5,3 & 5,8 \\
\hline
\end{tabular}

Results of research according to the material wealth show that a significant number of respondents assess the financial position as an average, and this situation has varied towards deterioration in recent years. Dynamics of respondents' answers for 2013-2017 to the second possible answer is of annual increase that has an adverse effect on population's life quality. The number of respondents who are well off in dynamics for 2013-2017 tends to decrease that also demonstrates a decline in quality of life of the population. The number of respondents who assess the situation as "very poor" grows. In turn, the number of rich respondents tends to decrease.

The level of income differentiation in the Russian Federation within Jeanie's coefficient during 2013-2017 is at the level of 0.4 (the standard from 0 to 1 ). The countries having the same degree of concentration of income in the range of 0.3-0.4 are Italy, Israel, Lithuania, Spain, Ireland, Great Britain, Portugal. A half of Russian regions at the level of stratification of society is closer to the European countries with developed economy, and other half of regions gravitates to indicators backward, poor and developing countries.

Thus, the level of material wealth in the period under review tends to decrease that is a negative tendency. The material wealth of citizens is not in time behind rates of inflation and increase in prices. An annual decrease in material wealth influences a decrease in population with monetary income lower than the size of the living level that respectively exerts impact on food security.

The next question was "Assess the Satisfaction with Separate Aspects of Quality of Life on Five-point System" for determination of the satisfaction level of the respondents with quality of food, water, health, life in general (table 2) [15].

TABLE II. ASSESSMENT OF SATISFACTION WITH SEPARATE ASPECTS OF LIFE QUALITY, IN PERCENT

\begin{tabular}{|l|c|c|c|c|c|}
\hline & 2013 & 2014 & 2015 & 2016 & 2017 \\
\hline \multicolumn{7}{|c|}{ Points } & 2013 faction with food quality \\
\hline "4" & 33,9 & 31,7 & 31,3 & 31,9 & 31,5 \\
\hline "3" & 18,2 & 19,1 & 19,6 & 18,7 & 19,4 \\
\hline "5" & 20,7 & 19,8 & 20,2 & 19,6 & 18,2 \\
\hline "1" & - & 5,1 & 4,8 & 4,5 & 5,7 \\
\hline "2" & 9,7 & 10,1 & 8,4 & 9,3 & 9,7 \\
\hline No answer & 17,5 & 14,2 & 15,7 & 16,0 & 15,5 \\
\hline \multicolumn{7}{|c|}{ Satisfaction with water quality } \\
\hline "3" & 21,8 & 22,3 & 23,0 & 23,7 & 23,2 \\
\hline "4" & 38,0 & 37,4 & 36,8 & 35,4 & 34,6 \\
\hline "5" & 22,1 & 21,5 & 20,9 & 19,6 & 18,7 \\
\hline
\end{tabular}

\begin{tabular}{|l|c|c|c|c|c|}
\hline "1" & - & 1,2 & 1,3 & 2,8 & 3,9 \\
\hline "2" & 13,4 & 14,0 & 13,9 & 14,3 & 15,1 \\
\hline No answer & 4,7 & 3,6 & 4,1 & 4,2 & 4,5 \\
\hline \multicolumn{7}{|c|}{ Satisfaction with a health condition } \\
\hline "4" & 39,9 & 38,2 & 36,4 & 37,1 & 36,3 \\
\hline "3" & 25,9 & 26,4 & 26,9 & 25,2 & 26,1 \\
\hline "5" & 18,1 & 17,7 & 16,5 & 15,7 & 15,0 \\
\hline "2" & 9,3 & 10,6 & 11,1 & 11,7 & 10,9 \\
\hline "1" & 1,1 & 2,9 & 4,7 & 6,4 & 8,4 \\
\hline No answer & 5,7 & 4,2 & 4,4 & 3,9 & 3,3 \\
\hline \multicolumn{7}{|c|}{ Satisfaction with life in general } \\
\hline "4" & 41,4 & 40,2 & 39,8 & 38,6 & 38,1 \\
\hline "5" & 22,9 & 23,1 & 22,7 & 23,3 & 23,9 \\
\hline "3" & 15,2 & 14,5 & 14,1 & 13,7 & 12,9 \\
\hline "2" & 9,0 & 9,6 & 10,2 & 10,6 & 11,0 \\
\hline "1" & 2,0 & 5,0 & 5,0 & 6,7 & 6,4 \\
\hline No answer & 9,5 & 7,6 & 8,2 & 7,1 & 7,7 \\
\hline
\end{tabular}

The satisfaction with food quality is one of important indicators of wellbeing of the population. Most of the interviewed respondents have highly appreciated the satisfaction with food quality - on "4" points and above (in the sum of $33,9 \%$ in $2013,31,7 \%$ in $2014,31,3 \%$ in $2015,31,9$ in 2016 and $31,5 \%$ in 2017). Despite high value of an indicator, the authors observed the negative tendency on this indicator of life quality. Also assessment of satisfaction of the population with quality of water - on looks "4" and higher than a point (in the sum of $38 \%$ in $2013,37,4 \%$ in $2014,36,8 \%$ in 2015 , $35,4 \%$ in 2016 and $34,6 \%$ in 2017). The satisfaction of the population with water quality also tends to decrease for the last five years.

One of important indicators of life quality is the health indicator. Most of the interviewed respondents distinguish rather high degree "4" and above points with satisfaction with a condition of own health.

The generalizing indicator is the satisfaction with life which represents value judgment by the identity of level of realization of the material and spiritual needs, degrees of accommodation comfort [3]. In our research the satisfaction with life is estimated by a considerable number of respondents.

The conducted research confirms necessity of monitoring of population's life quality indicators, independent structures which will consider real indicators of population's life quality. In relation to this research, the authors offer the system of the generalized complex indicators of assessment of population's life quality taking into account the place in infrastructure of the state (Figure 1).

The developed system of the generalized complex indicators of population's life quality assessment, taking into account its place in infrastructure of the state, will give the chance fully in more detail and approach qualitatively questions of increase in food security.

Thus, the balanced system of complex indicators directed to improvement of population's life quality is capable to solve the problems about food security, and, therefore, to make an essential contribution to dynamic social and economic development of the whole country in general. 


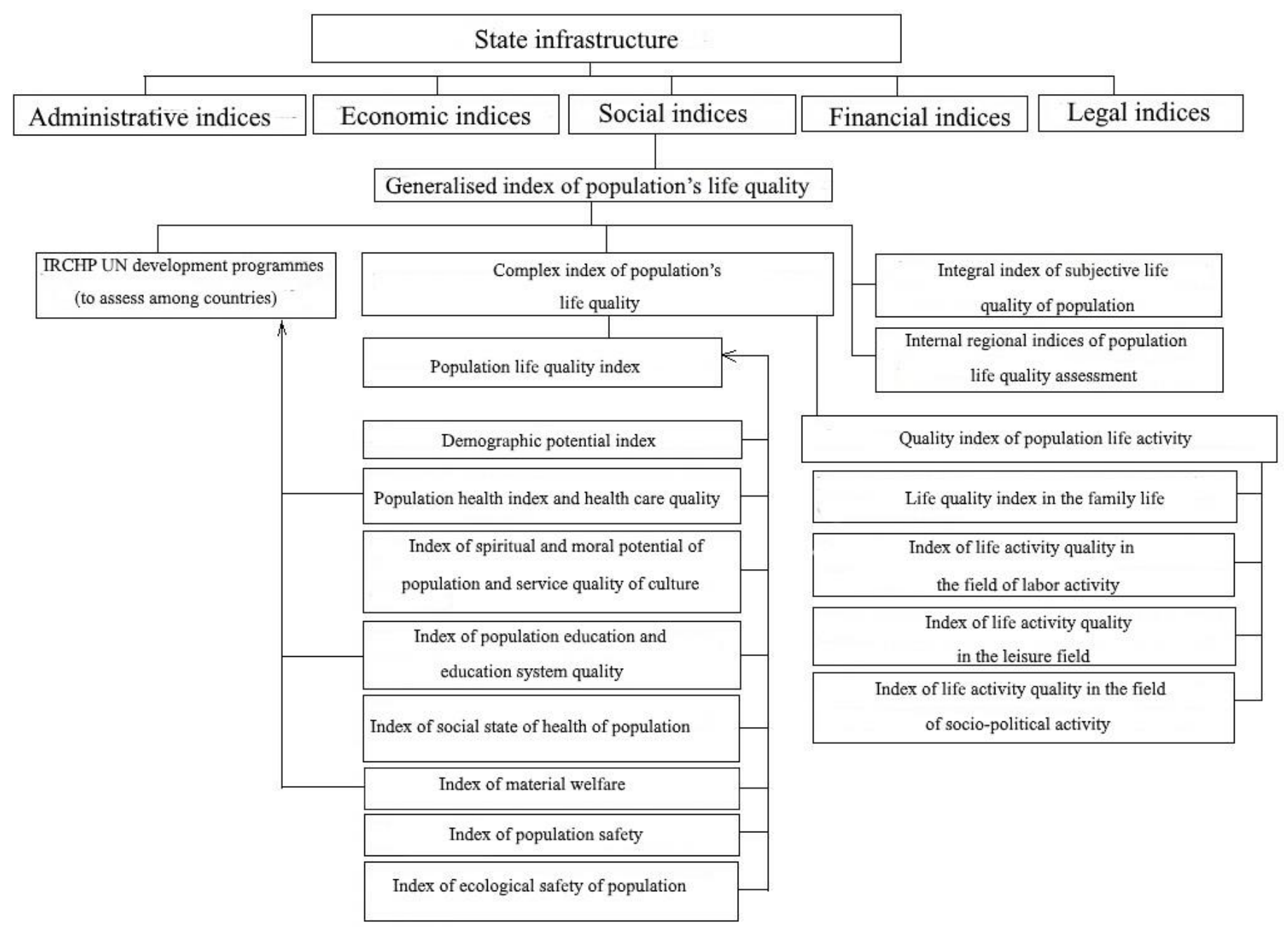

Fig. 1. The system of the generalized complex indicators of population's life quality assessment in infrastructure of the state

\section{CONCLUSION}

Food supply of the population available and qualitative food of particular importance are a factor of increase in the level and population's life quality.

In this regard, critical issues of increase in the level and quality of population's life within food security in Russia are:

- development of the domestic food market infrastructure;

- timely providing the population of the country with main types of food due to own domestic production;

- a quality guarantee and the high level of safety of the consumed food at the level of the state;

- state regulation of food prices;

- modification and additions in the current legislation and normative legal acts for the purpose of uniform body formation of the state control of quality and safety of foodstuff;
- stable ensuring growth in incomes of the population for the purpose of increase in living standards;

- establishment of strict state regulation of the socially important food prices;

- development of the system of targeted food aid to the population;

- decrease in the level of internal and external threats of violation of the country food security.

Only the measures named above will be able to give a tangible result in the long term, and provide improvement of population's life quality and food security of the country.

\section{FINDINGS}

Results of the research demonstrate that the satisfaction of the population with the separate aspects of life quality exerting impact on food security in general was reduced during 20132017. Decrease in values of the studied indicators 
demonstrates the general decline in population's life quality that is contrary to official statistics data.

The conducted research confirms necessity of monitoring population's life quality indicators by independent structures which could present real in population's life quality indicators. This research of respondents' opinions would allow one to reveal existence of positive and negative changes of population's life quality in a retrospective in five years and to make more effective administrative decisions.

In our opinion, researches of population's life quality have been based on the wrong conceptual installations which are not considering interrelation between continuous reduction of level of the population income and change of structure of consumption of food towards cheaper and low-quality products that as a result has pernicious effect on health of the nation in general. Annual growth of consumption of cheaper products (generally potatoes and bakery products) as researches show, excess admissible rational norms, in fact, are a characteristic result of impoverishment of the population. The existing level of the population income does not allow consuming food in necessary volume according to rational norms of consumption that as a result reduces the level of the country food security.

The system of the generalized complex indicators of population's life quality assessment offered by the authors, taking into account its place within priority state programs, will allow one to give more objective picture of the current state of food security in the country.

\section{ACKNOWLEDGEMENT}

The authors are grateful to professor A.N. Makarov for the stated valuable recommendations in the conceptual plan and for the editorial help in preparation of the article for the publication.

\section{References}

[1] E.G. Animitsa, A.M. Elokhov, V.A. Sukhihk, Quality of life of the largest city population. Yekaterinburg: Publishing house of the Ural state economic university, 2000, p. 262.

[2] I.V. Bestuzhev-Lada, Methodological problems of a research of quality, level and way of life. Modern concepts of level, quality and way of life, 1978, pp. 22-41.

[3] E.V. Davydova, A.A. Davydov, Measurement of quality of life. M: Institute of sociology of RAS, 1993, p. 52.

[4] N.V. Klimova, Food security - a basis of ensuring economic security of the region. Basic researches, 2012, vol. 9-1, pp. 214-219.

[5] A.N. Makarov, Food security in the context of the landed property reform (assessment, a constructive position), Land management, the inventory and monitoring of lands, 2017, vol. 11, pp. 19-25.

[6] N.V. Mordovchenkov, M.G. Nikolaeva, Regional infrastructure as factor of improvement of quality of life of the population: monograph. $\mathrm{N}$. Novgorod: 2010.

[7] M.A. Mikhalenko, Ensuring food security of Russia as condition of improvement of quality of life. Scientific works of the Moscow humanities university, 2017, vol. 3, pp. 129-137.

[8] N.M. Rimashevskaya, V.K. Bochkaryova, G.N. Volkova, L.A. Migranova, E.A. Olshanskaya, Regional problems of employment and standard of living. Russia in the globalized world. Strategy of competitiveness. M: Science, 2015, p. 306.

[9] V.I. Samarukh, Economic security of the Russian Federation in the modern world. News of higher education institutions. Investments. Construction. Real estate, 2016, vol. 1(16), pp. 63-67.

[10] O.S. Sausheva, Food security in the system of the relations of the standard of living, 2006, p. 182.

[11] I.A. Sergeyev, A.Yu. Sergeyev, Threats of food security of Russia. Food policy and safety, 2014, vol. 1, pp. 13-24.

[12] Y.S. Khromov, Problems of food security of Russia: international and internal aspects. M: RISI, 1995, p. 73.

[13] M.S. Chebotaryova, Food security in Russia and the world: essence and problems. Young scientist, 2012, vol. 8, pp. 149-151.

[14] A.A. Shabunova, M.V. Morev, A.I. Rossosh, G.V. Belekhova, Standard of living and social reality: monitoring of changes. Vologda: ISERT RAHN, 2015.

[15] I.A. Shchetkina, Quality of life as indicator of social development of the region. Scientific notes of ZABGU. 2013, https://cyberleninka.ru/article/n/kachestvo-zhizni-kak-pokazatelsotsialnogo-razvitiya-regiona. 